\title{
Strategic Adaptation as a Way of Managing Organizational Changes in the Context of Implementing a Safety Oriented Enterprise Management Approach
}

\author{
Nataliia Havlovska ${ }^{1}$, Olena Illiashenko ${ }^{2}$, Olena Konoplina ${ }^{2}$, Inna Shevchuk ${ }^{3}$, \\ Anastasiia Hlynska ${ }^{4}$, Vadym Prytys ${ }^{1}$ \\ ${ }^{1}$ Khmelnitsky National University, Khmelnitsky, Ukraine \\ ${ }^{2}$ O.M. Beketov National University of Urban Economy, Kharkiv, Ukraine \\ ${ }^{3}$ Yuzkov Khmelnytskyi University of Management and Law, Khmelnytskyi, Ukraine \\ ${ }^{4}$ Kherson National Technical University, Kherson, Ukraine
}

\begin{abstract}
Strategic adaptation is one of the effective approaches of enterprise management, which is based on implementing safety-oriented management, taking into account current dangers, threats and risks. First, such adaptation is associated with changes in the enterprise management system, aimed at establishing appropriate communications between the structural divisions of the enterprise, the distribution of authorities and responsibility for making decisions, counteracting the opportunistic behavior of employees due to changes in the organizational structure of the enterprise management. In the process of research, the use of L. Greiner's Model of Organizational Change was proposed (for a generalized picture of the sequence of organizational changes), and the Change Curve Model by J. Duck was adapted (when developing a fundamental sequence of measures to identify the main causes of workers' resistance and choose ways to counter it). This allows optimizing the processes of strategic adaptation within the safety oriented approach of enterprise management.
\end{abstract}

Keywords - adaptation, strategic management, economic security, organizational change, model.

DOI: $10.18421 /$ TEM93-29

https://doi.org/10.18421/TEM93-29

Corresponding author: Nataliia Havlovska, Khmelnitsky National University, Khmelnitsky, Ukraine. Email: nataligavlovska @gmail.com

Received: 16 March 2020.

Revised: 14 June 2020.

Accepted: 23 June 2020.

Published: 28 August 2020.

(c) BY-NC-ND (C) 2020 Nataliia Havlovska at al; published by UIKTEN. This work is licensed under the Creative Commons Attribution-NonCommercial-NoDerivs 4.0 License.

The article is published with Open Access at www.temjournal.com

\section{Introduction}

Downturn of the crisis within the socio-economic development of society causes complications for the functioning in most of the enterprises. Accordingly, companies are forced to formulate new protective approaches to adequately respond to existing threats and strategically adapt their activities. Moreover, it is the strategic approach to adaptation change that is the key to obtaining long-term positive results. Such adaptation requires organizational change, which is ensured by new management tools and approaches [5]. One of the progressive approaches to managing organizational change in the field of economic security is security-oriented management. It aims to create such conditions for the enterprise, under which preventive measures at the level of the enterprise management system as a whole will have a corresponding positive impact on the economic security and allow the management of enterprises to implement the overall strategy for its development. At the same time, enterprise management should be clearly aware of the features regarding the functioning of the enterprise and take into account the influence of the environment, which in most cases has a negative nature. Correspondence of the economic security system to the enterprise management system, within the framework of the safety oriented approach, is laid down during the implementation of the enterprise economic security system in the enterprise management system. Such implementation will inevitably cause organizational changes in the enterprise management system, that is, its adaptation, which should ensure the adaptation of the enterprise management system to an emergence of a new subsystem or super-system and, accordingly, to a further use of mechanisms of the enterprise economic security system.

Foundations for theoretical and instrumental basis of economic security, a foundation of its methodology are 
laid in modern studies on an enterprise economic security [6], [8], [10]. However, changes in the enterprise management system during the creation and objectification of the enterprise economic security system is a new and little-studied issue. Since the formation of a scientific direction for managing organizational changes has not yet been completed, we can only talk about a development of conceptual and scientific foundations and a creation of an appropriate methodology and mechanisms for managing changes, especially in the field of economic security. These processes are mutual: the strategic adaptation of the enterprise management system in the form of certain changes is necessary to place the enterprise economic security system (as a subsystem or super-system) in it. However, changes in the activity and management of an enterprise (and changes in the enterprise management system is no exception) affect both an enterprise economic security and its system, and the operation of the mechanisms of such a system.

Adaptation of the enterprise management system in the form of a set of interrelated changes in response to the implementation of the economic security system is a complex process, for its description in the theory of management models of organizational changes were developed. These models are model of business transformation by K. Lewin [9], iceberg model by Stanley N. Herman [11], Transforming Organizations model by F. Gouillart \& J. Kelly [3], J. Kotter's consept
[7], J. Duck's change curve model [2], theory E and theory $\mathrm{O}$ of organizational change by $\mathrm{M}$. Beer and $\mathrm{N}$. Nohria [1], which were formed under the influence of technological and information development at the end of the 20th century, and therefore took into account the social and technical components of an organization. Any of the models of organizational changes contains a set of management methods and tools. Their use of which is aimed at identifying elements (subsystems) or processes of the enterprise management system as objects of change, forming tools for influencing them, determining a sequence of its use, of course, is a useful practice in implementing safety oriented approach to enterprise management.

\section{Research Method}

To implement measures for the strategic adaptation of the enterprise management system to a new subsystem or super-system and developed mechanisms that ensure its functioning and management, appropriate approaches have been developed that reflect the main goals, objectives and initiatives of adaptation, its functional areas and requirements for implementation in terms of managerial levels. Schematic diagram of strategic adaptation of the enterprise management system to a new subsystem or super-system - the enterprise economic security system (EESS) is shown in Fig. 1.

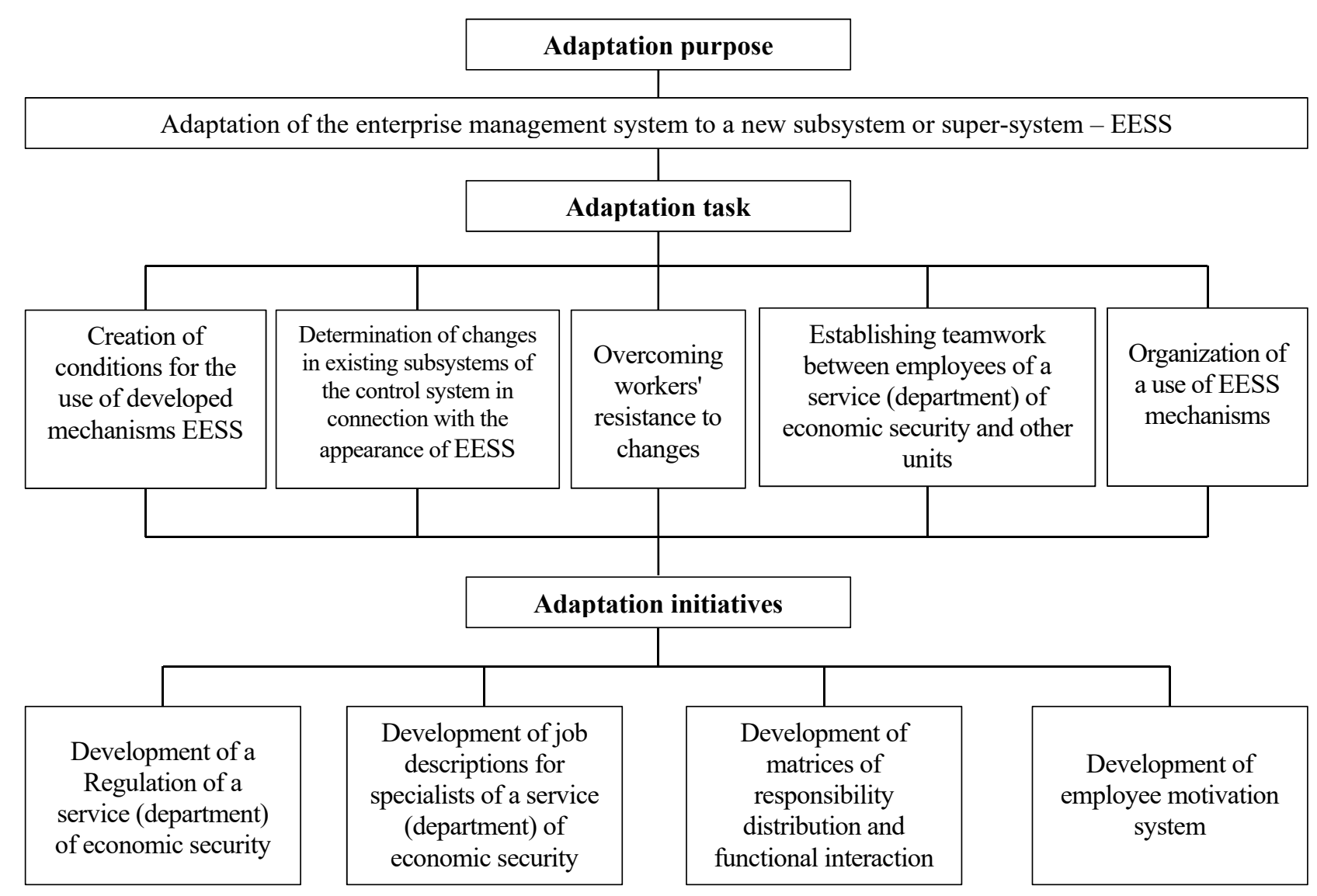

Figure 1. Scheme of strategic adaptation of the enterprise management system to a new subsystem (or super-system) 
The implementation of the economic security system involves not only changes in the enterprise management system, but also the management of these changes, their controllability, as lack of control can slow down the implementation process, and in some cases lead to completely opposite results due to a strong resistance of individual employees or structural units of an enterprise. Moreover, the higher the hierarchy of workers who are resisting, the more structural units does not perceive the economic security system, the more real the danger of an impossibility of implementing a system is.

Changes that make up the essence of a strategic adaptation of the enterprise management system to an implementation of the enterprise economic security system should take place in two directions - personal changes and organizational changes. To describe and analyze them, it is necessary to review a structure and correlation of components of the enterprise management system, which are most often considered from the standpoint of a functional approach.

The main goal of changes in the "hard" and "soft" areas of organizational life when implementing the enterprise economic security system in the enterprise management system is to form a unified attitude of all employees regarding the perception of economic security as the main condition for the activity and development of the enterprise, and to ensure economic security. It requires a change in approaches to perform tasks in accordance with the job descriptions of employees. Foundation for a formation of a unified attitude of workers towards perception and ensuring economic security is a formation of a complete "strategic security of thinking", which should be manifested at all stages of a formation and adoption of managerial decisions in structural units and an enterprise as a whole.

Strategic organizational changes in the enterprise management system in connection with an implementation of the enterprise economic security system of an enterprise occur at almost all management levels (Fig. 2). At the level of individual workers, organizational changes in the enterprise management system in connection with the implementation of the economic security system of the enterprise are manifested in a change in the functions, tasks, responsibility and subordination, the order of actions at the workplace, the implementation of new actions or the cessation of those actions that were performed earlier, and the need to fill new documents related to economic security. These changes are formalized in the work and job descriptions of employees.

At the level of structural units, organizational changes are manifested in the emergence of zones of responsibility in which security facilities are located; in expanding the competencies of the unit due to the need to evaluate jointly the security status of the security facilities (or to provide information in some format to the service (department) with the service (department) of economic security, if the assessment falls within its exclusive competence), to participate in the selection and the application of security features; perform individual actions within the selected security method.

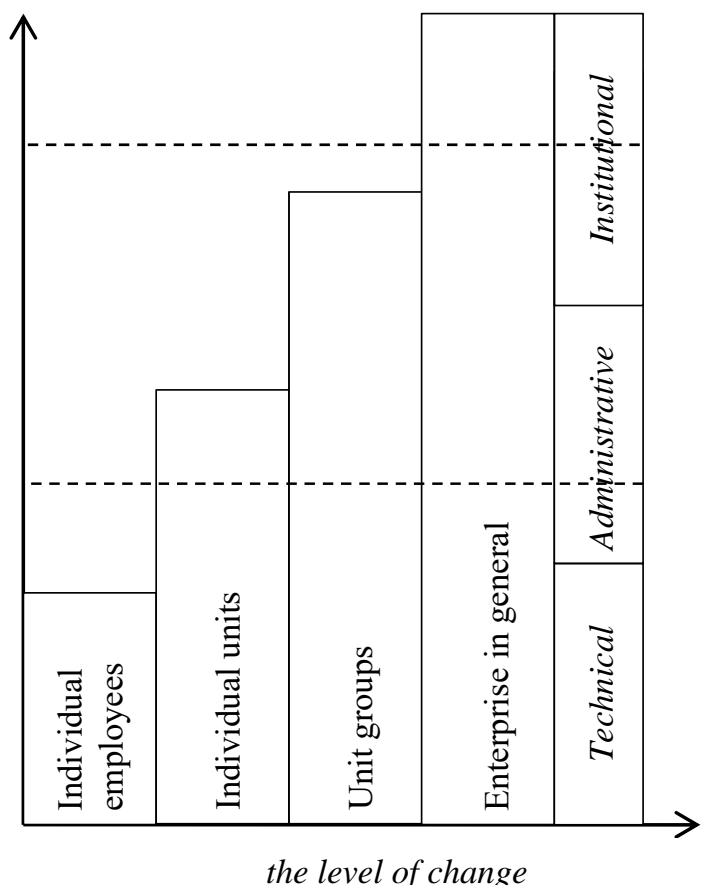

Figure 2. Organizational changes in the enterprise management system by management levels

Documentary organizational changes at the level of individual structural units should be reflected in the regulations on units, for which, when creating the economic security service, they have to be reviewed and reapproved.

At the level of unit groups (employees), organizational changes in the enterprise management system most often relate to the interaction between divisions and mid-level executives regarding the protection of an enterprise economic security objects. Protection of security facilities of the enterprise economic security system concerns almost all departments, and therefore, changes in the interaction of departments and managers for the protection of security facilities occur in all areas of interaction (the order of interaction, subordination, functions and tasks of departments and employees, management organization). Documentary changes at this level should be reflected in maps of processes and procedures, in maps of information flow.

At an enterprise level in general changes cover not only all processes and elements of the management system, but also vectors, landmarks, goals and principles of management. Thanks to changes in the enterprise management system in general, economic security is recognized as a main condition for its activity, its maintenance is one of strategic goals. 
When implementing organizational changes in connection with the creation of the economic security service (department) at an enterprise, it is necessary to realize and take into account that the dynamics and intensity of changes are different in structural units and managerial levels.

\section{Results}

For a generalized reflection of the sequence of organizational changes associated with the implementation of the enterprise economic security

\section{Stage 1}

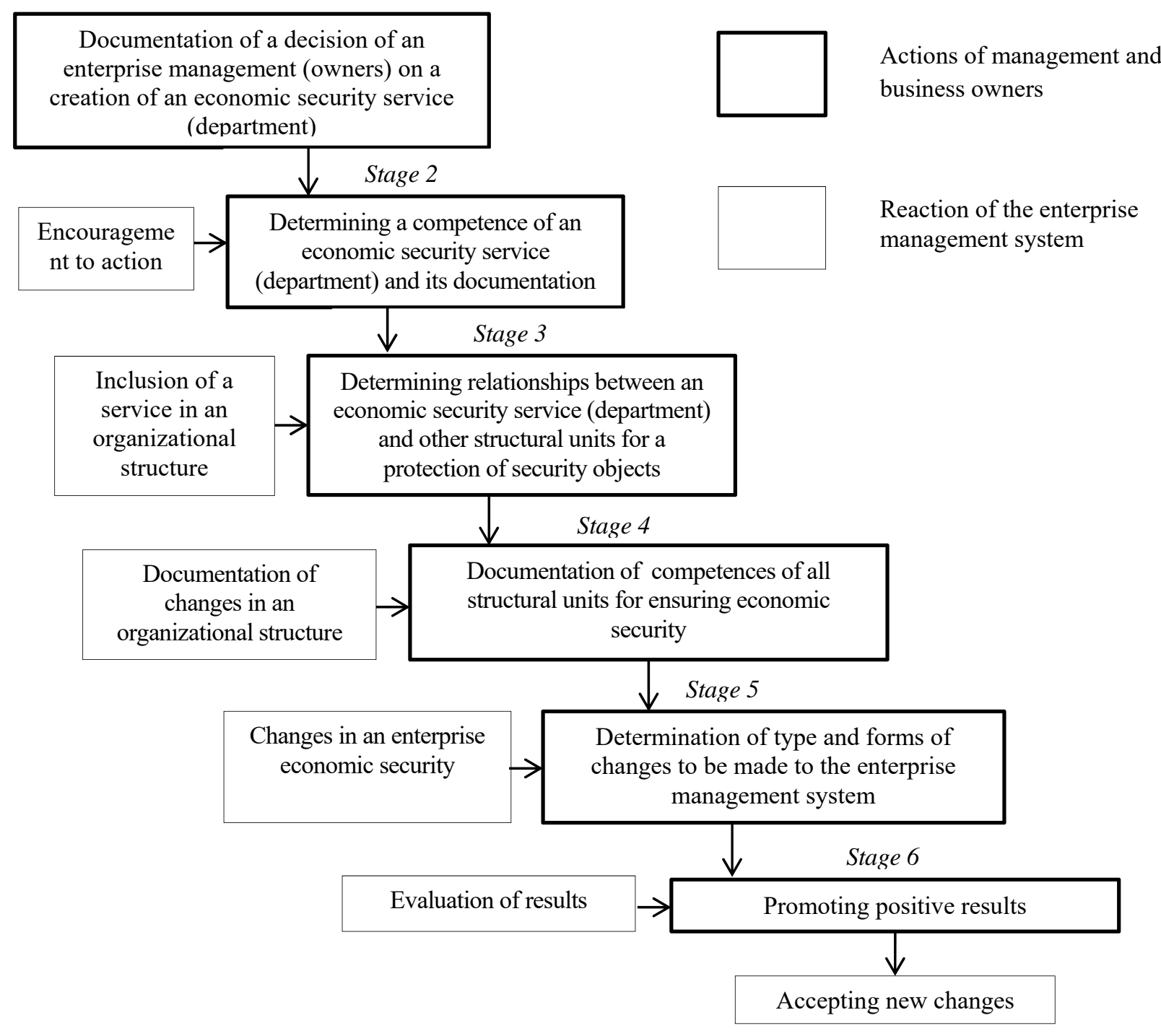

system in the enterprise management system, it is advisable to use the model of organizational changes by L. Greiner filled with specific content in order to reflect the sequence of actions for the implementation of the enterprise economic security system in the enterprise management system (Fig. 3).

We can consider in more detail the main stages of organizational changes at an enterprise for the implementation of the enterprise economic security system in the enterprise management system using the adapted L. Greiner model.

Figure 3. Model of organizational changes by L. Greiner, adapted to the implementation of the enterprise economic security system in the enterprise management system *

* adapted [4]

Stage 1. Management and owners of an enterprise, recognizing economic security as an important condition for activity, recognizing the importance and necessity of creating a system of economic security, which allows to get an idea of a state of economic security at a system level, decide on the implementation of a system and create the economic security service (department) at an enterprise.

Stage 2. Enterprises determine competencies of the economic security service (department), which are necessarily documented - they are developed, approved in accordance with the procedure adopted by an enterprise and put into force the Regulation of economic security service (department). 
Stage 3. The inclusion of the economic security service (department) in an enterprise organizational structure provides for a number of actions to establish the relationship of a service (department) with other structural units on a protection of security facilities within the enterprise economic security system. Such actions include collecting information about threats, its joint processing, determining the likelihood of implementation and consequences of realization of threats to security objects, choosing enterprise actions for a specific protection method (evading threats, neutralizing them, accepting threats, etc.), determining the cost of these actions etc.

Stage 4 . The large number and variety of these actions require their ordering and documenting the execution.

Stage 5. The economic security system of the enterprise is constantly changing. These changes in the system arise as a result of the functioning of the system control mechanism. The occurrence of these changes is due to the transition of the system to a qualitatively new state in order to fulfill its purpose. Changes in the economic security system of an enterprise should be reflected in the enterprise management system.

Stage 5. The economic security system of an enterprise is constantly changing. These changes in a system arise as a result of the functioning of a system control mechanism. The occurrence of these changes is due to the transition of the system to a qualitatively new state in order to fulfill its purpose. Changes in the enterprise economic security system of an enterprise should be reflected in the enterprise management system. If ignore changes in the enterprise economic security system and do not make appropriate changes to the enterprise management system, then contradictions between a system (enterprise management system) and its subsystem or supersystem (enterprise economic security system) will arise and deepen over time. This contradiction may adversely affect the protection of security facilities, and in the end, ensuring an enterprise economic security.

Stage 6. At the last stage, measures to encourage employees of an enterprise who took part in organizational changes associated with the implementation of the enterprise economic security system in the enterprise management system are necessary. Despite the traditional meaning of this stage, it cannot be underestimated. In modern management, it is recommended that employees are to be widely involved in organizational changes. It is advisable to take advantage of L. Greiner's opinion on the distribution of powers between levels of government (Fig. 4), because safety-free activities are those activities that require compliance with a certain level of secrecy and a regime for using relevant information.
On the one hand, it makes sense to involve as many employees as possible in changes at the enterprise management system, but, on the other hand, it is inappropriate due to specifics of the economic security service (department) (at least because managers and employees do not need to know what powers have services regarding verifying their activity).

\begin{tabular}{|cc|}
$\begin{array}{c}\text { Allocation of powers (balance between top } \\
\text { management and subordinates) }\end{array}$ \\
\hline $\begin{array}{c}\text { One-sided action } \\
\text { (full retention of } \\
\text { authority by } \\
\text { senior }\end{array}$ & $\begin{array}{c}\text { Delegation of authority } \\
\text { (full or partial } \\
\text { management) }\end{array}$ \\
$\begin{array}{c}\text { delegation of authority } \\
\text { to lower levels of } \\
\text { management) }\end{array}$
\end{tabular}

Figure 4. Allocation of authority to make organizational changes related to the implementation of the enterprise economic security system in the enterprise management

$$
\text { * adapted [4] }
$$$$
\text { system * }
$$

Making changes to the enterprise management system in connection with the implementation of the enterprise economic security system is faced with a problem of a circle of workers involved in such changes. The occurrence of the problem is due to specifics with regard to an activity of the economic security service (department), which objectivize a system of an enterprise economic security.

Filling the change model by L. Greiner with specific content in the context of the implementation of the economic security system in the enterprise management system provides the development of tools for the distribution of powers, responsibility and communications between the economic security service (department) and structural units of the enterprise. The matrix method was used in developing such tools, which allows forming matrices of responsibility distribution and matrices of functional interaction.

The liability allocation matrix shows the distribution of actions from officials and structural units of an enterprise to ensure the enterprise economic security. In general, it is impossible to provide such a matrix, therefore, Table 1 provides a fragment of the liability allocation matrix generated for a particular enterprise.

The functional interaction matrix shows the distribution of the competence within the economic security service between employees of the service. In such a matrix, the competencies of the service (department) of economic security are divided into separate works or actions. It serves as the basis for determining the duties of employees of the service (department) and the development of their job descriptions. 
Building a functional interaction matrix is similar to constructing liability distribution matrix. Table 2 provides a fragment of a functional interaction matrix that is built for a particular enterprise.

Table 1. Liability distribution matrix (fragment)

\begin{tabular}{|c|c|c|c|c|c|}
\hline Types of work & $\begin{array}{c}\text { Top } \\
\text { management }\end{array}$ & $\begin{array}{c}\text { Economic } \\
\text { security } \\
\text { service } \\
\text { (department) }\end{array}$ & $\begin{array}{l}\text { Financial and } \\
\text { economic } \\
\text { department }\end{array}$ & $\begin{array}{l}\text { Marketing } \\
\text { department }\end{array}$ & $\begin{array}{l}\text { Production } \\
\text { department }\end{array}$ \\
\hline $\begin{array}{l}\text { Elaboration of Regulation of } \\
\text { Economic Security Service } \\
\text { (Department) }\end{array}$ & $A_{3}$ & $I_{3}$ & $H_{1}$ & $H_{1}$ & $H_{1}$ \\
\hline $\begin{array}{l}\text { Analysis of nature and causes of } \\
\text { identified threats }\end{array}$ & $\mathrm{A}_{3}$ & $I_{5}$ & $\mathrm{H}_{2}{ }^{1}$ & $\mathrm{H}_{2}{ }^{1}$ & $H$ \\
\hline $\begin{array}{l}\text { Development of tools for controlling } \\
\text { activities of structural units and their } \\
\text { managers }\end{array}$ & $\mathrm{A}_{3}$ & $I_{2}$ & $\mathrm{H}_{3}{ }^{3}$ & $\mathrm{H}_{3}{ }^{2}$ & $H_{1}{ }^{3}$ \\
\hline $\begin{array}{l}\text { Order of submission of operational } \\
\text { information by structural units to the } \\
\text { economic security service } \\
\text { (department) }\end{array}$ & $\mathrm{A}_{3}$ & $H_{1}$ & $I_{4}^{2}$ & $I_{2}^{4}$ & $I_{3}^{2}$ \\
\hline $\begin{array}{l}\text { Analysis of the implementation of the } \\
\text { recommendations of the economic } \\
\text { security service }\end{array}$ & $\mathrm{A}_{3}$ & $I_{4}$ & $H_{1}$ & $H_{1}$ & $H_{1}^{2}$ \\
\hline 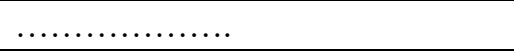 & & & & & \\
\hline
\end{tabular}

Table 1 has the following accepted designations: A - adoption, $H$ - harmonization, I - implementation; the lower index indicates the unit from which the information comes, and the upper indicates the unit to which the information is transmitted.

Table 2. Functional interaction matrix (fragment)

\begin{tabular}{|l|c|c|c|c|c|}
\hline \multirow{2}{*}{ Competencies (work) } & \multicolumn{4}{|c|}{ Employees of the economic security department (department) } \\
\cline { 2 - 6 } & Manager & Analyst & Analyst & $\begin{array}{c}\text { Economic } \\
\text { Security } \\
\text { Specialist }\end{array}$ & $\begin{array}{c}\text { Economic } \\
\text { Security } \\
\text { Specialist }\end{array}$ \\
\hline $\begin{array}{l}\text { Identification and approval of requirements } \\
\text { for security activities in the areas }\end{array}$ & M, E & & $\mathrm{P}$ & $\mathrm{P}$ & $\mathrm{P}$ \\
\hline $\begin{array}{l}\text { Gathering and monitoring information on } \\
\text { operational activities of structural units; } \\
\text { counterparty activities; dynamics of economic } \\
\text { processes in economics, etc. }\end{array}$ & $\mathrm{E}$ & $\mathrm{A}$ & $\mathrm{A}$ & $\mathrm{D}$ & $\mathrm{D}$ \\
\hline $\begin{array}{l}\text { Analysis of internal and external information } \\
\text { for potential threats }\end{array}$ & $\mathrm{E}$ & $\mathrm{P}$ & $\mathrm{P}$ & $\mathrm{D}$ & $\mathrm{D}$ \\
\hline $\begin{array}{l}\text { Control of activity of structural divisions } \\
\text { Conducting inspections in structural units of } \\
\text { an enterprise }\end{array}$ & $\mathrm{M}$ & $\mathrm{D}$ & $\mathrm{D}$ & $\mathrm{M}$ & $\mathrm{M}$ \\
\hline$\ldots \ldots \ldots \ldots \ldots . \ldots . \ldots$ & & & & $\mathrm{M}$ \\
\hline
\end{tabular}

Table 2 has the following accepted designations: $M$ - is responsible for the implementation of the work (action), organizes its performing, prepares the final document; $D$ - provides the necessary source data and information; $P$ participates in the performance of work (action); A - approves a prepared document or individual issues in the process of performing work (actions); E - makes decisions, approves, signs documents.

Using the proposed matrices (liability distribution and functional interaction) allows specifying the competencies regarding the economic security service (department) to the level of a specific job, the implementation of which can be included in the job responsibilities of service specialists.

The implementation of organizational changes in an enterprise, due to any prerequisites or reasons, is always a complex process. Indeed, any change in a person's life, including a professional one, most often encounters resistance, especially if this change is associated with the emergence of new duties, the abandonment of the usual professional duties, the need to learn new techniques in work, gain new knowledge, etc. D. Y1lmaz and G. Kilıçoğlu noted the threat of loss the influence of certain groups of workers on decision- 
making or resource allocation, which is caused by administrative or technological changes in the organization [12]. In addition, as noted by D. Y1lmaz and G. Kılıçoğlu, when people encounter new unfamiliar methods or difficulties and troublesome situations, they can idealize the past; strive to return to the past way of solving cases [12]. The intensity of staff resistance depends on the state of the corporate culture, the staff age structure, the level of their qualifications, and the quality and timeliness of the preparatory work for expected changes.

The resistance of a staff when creating the economic security service (department) and the changes that occur in the enterprise management system most often are hidden. Only top managers can openly resist at the stage of deciding to create a service (department). The interest and enthusiasm of employees in creating the economic security service (department) and changes arising in the enterprise management system may be more related to the personal benefits they receive.

To identify individual workers and their groups that are more likely to resist (and not always intentionally) the implementation of the economic security system in the enterprise management system, the possible causes of resistance are summarized (Table 3 ).

Table 3. The main causes of staff resistance and its consequences

\begin{tabular}{|l|l|l|}
\hline \multicolumn{1}{|c|}{ Nature of resistance } & \multicolumn{1}{|c|}{ Cause } & \multicolumn{1}{|c|}{ Consequences } \\
\hline $\begin{array}{l}\text { Personal interest of individual } \\
\text { employees }\end{array}$ & $\begin{array}{l}\text { Expectation of personal losses as a result } \\
\text { of the activities of the economic security } \\
\text { service (department) }\end{array}$ & $\begin{array}{l}\text { "Political" behavior, creating pressure } \\
\text { groups }\end{array}$ \\
\hline $\begin{array}{l}\text { Misunderstanding of the strategic goals } \\
\text { and objectives of the economic security } \\
\text { service (department) }\end{array}$ & $\begin{array}{l}\text { Low level of trust in enterprise } \\
\text { management }\end{array}$ & Rumors, gossip \\
\hline $\begin{array}{l}\text { Negative assessment of the } \\
\text { consequences of establishing the } \\
\text { economic security service (department) }\end{array}$ & $\begin{array}{l}\text { Inadequate perception of the developed } \\
\text { measures, obtaining information from } \\
\text { unreliable and unscrupulous sources }\end{array}$ & Open disagreement of a stuff \\
\hline $\begin{array}{l}\text { Feeling of employees' qualification } \\
\text { unreadiness for activities of the } \\
\text { economic security service (department) }\end{array}$ & $\begin{array}{l}\text { People fear that they do not have the } \\
\text { necessary skills or abilities }\end{array}$ & $\begin{array}{l}\text { Behavior aimed at maintaining one's } \\
\text { own prestige }\end{array}$ \\
\hline $\begin{array}{l}\text { High level of unpredictability that may } \\
\text { accompany the creation and operation } \\
\text { of the economic security service } \\
\text { (department) }\end{array}$ & $\begin{array}{l}\text { Increasing feelings of distrust, } \\
\text { conservatism, negative attitude to any } \\
\text { changes }\end{array}$ & $\begin{array}{l}\text { Make preliminary changes } \\
\text { conversations with employees }\end{array}$ \\
\hline $\begin{array}{l}\text { Doubts about the process and ways of } \\
\text { ensuring economic activity }\end{array}$ & $\begin{array}{l}\text { Distrust in the competence of change } \\
\text { initiators }\end{array}$ & $\begin{array}{l}\text { "Reference" behavior, the need to } \\
\text { involve experts and consultants whose } \\
\text { competence is undeniable }\end{array}$ \\
\hline
\end{tabular}

The data from Table 3 serve as the basis for identifying the causes of overt and covert, intentional or even unconscious resistance of the enterprise personnel when creating the economic security service (department). Moreover, this resistance is often the resistance to strategic changes in general, but not to the creation of the economic security service (department). Using the data from Table 3, we can find reasons for the development of tools to overcome the resistance of personnel to create the economic security service (department) of an enterprise.

The purpose of such tools is to transform employees' interests and inevitable expressions of emotions. It cannot be ignored. Of course, it is possible to create the economic security service (department) without taking these emotions into account, but ignoring them in the future threatens tension regarding the professional and personal relations of specialists in economic security and employees of other structural divisions, which appears in real life in the form of conflicts from time to time. Changes in the enterprise management system during the implementation of the economic security system will be effective only if no less attention is paid to the emotional and behavioral aspects than to information and technical ones.

The toolkit for overcoming personnel resistance is mainly known; it is used in overcoming personnel resistance to changes of any nature. Its use will make it possible to establish the types of negative attitudes towards changes caused by the creation of the economic security service (department) and related changes in the organizational structure of an enterprise (Table 4).

Based on the analysis of tools to overcome the resistance to changes, the "change curve model" by J. Duck was selected as the most effective tool in overcoming the resistance to creating a service (department) of economic security of an enterprise and changes in its organizational structure, which focuses on the emotional behavior of people accompanying any organizational changes [2].In this model, the process of changes is presented in the form of a sequence of proposed and controlled stages ("change curve model"): stagnation, preparation, implementation, testing for strength, and achieving the goal.

An adapted "change curve model" by J. Duck to the situation under consideration is given in Figure 5. 
Table 4. Types of negative attitude to changes caused by the creation of the economic security service (department)

\begin{tabular}{|c|c|}
\hline Types of negative attitude & Ways of overcoming \\
\hline $\begin{array}{l}\text { Rational: lack of understanding of the need } \\
\text { to create the economic security service } \\
\text { (department), confidence that its creation } \\
\text { is superfluous, lack of faith in the expected } \\
\text { effectiveness of the service (department), } \\
\text { expectations of the negative consequences } \\
\text { of organizational changes in connection } \\
\text { with the creation of the service } \\
\text { (department) }\end{array}$ & $\begin{array}{l}\text { Explain at meetings and meetings the need to create a service } \\
\text { (department) of economic security; } \\
\text { Describe the consequences of a lack of service (department); } \\
\text { Involve middle-level managers in determining the competencies of the } \\
\text { service (department), redistributing the powers and responsibilities of } \\
\text { structural divisions and officials; } \\
\text { Make changes to the management system in connection with the } \\
\text { implementation of the economic security system sequentially, fixing } \\
\text { changes after each stage of their sequence }\end{array}$ \\
\hline $\begin{array}{l}\text { Personal: fear of losing authority or } \\
\text { receiving additional work, responsibility } \\
\text { for its performance (non-performance); } \\
\text { unfamiliar work, unwillingness to learn to } \\
\text { perform it }\end{array}$ & $\begin{array}{l}\text { Making changes in wages in connection with the expansion of the range } \\
\text { of official duties associated with participation in safety securing activity; } \\
\text { Organize classes, trainings on the implementation of new types of work; } \\
\text { Decrease the level of responsibility for mistakes and faults made in the } \\
\text { first few months when performing new types of work; } \\
\text { Increase the number of employees of structural divisions, where the } \\
\text { volume of work increases significantly (according to the actual need and } \\
\text { availability) }\end{array}$ \\
\hline $\begin{array}{l}\text { Emotional: general tendency to actively or } \\
\text { passively resist any change, apathy for } \\
\text { initiatives, distrust of the motives that } \\
\text { caused the changes }\end{array}$ & $\begin{array}{l}\text { Explain in detail the reasons for creating the economic security service } \\
\text { (department) and talk about its competence; } \\
\text { Show how the changes in the enterprise management system will affect } \\
\text { the job responsibilities of each employee }\end{array}$ \\
\hline
\end{tabular}

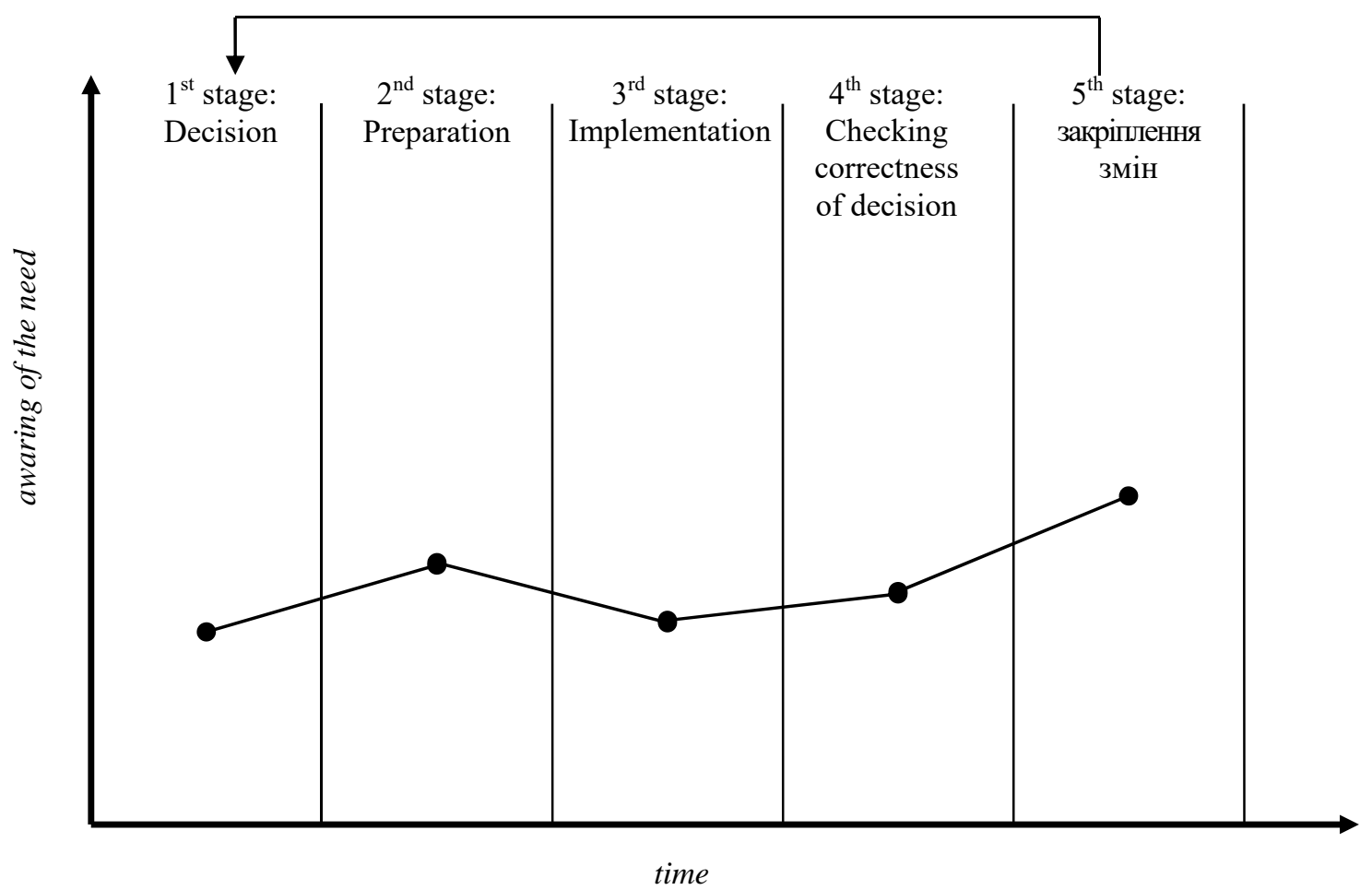

Figure 5. Stages of using the "change curve model" by J. Duck in overcoming staff resistance to the creation of the * adapted [2] enterprise economic security service (department) and changes in its organizational structure *

1. Stage "Decision": at this stage, owners of an enterprise or its management make a decision on the objectification of the developed system of the enterprise economic security by creating the economic security service (department).

2. Stage "Preparation": at this stage, issues of documenting the creation of the economic security service (department) (determination of staffing, choice of premises, solving issues of technical equipment, etc.) are decided, competencies of the service (department) are determined, forms of its interaction with other structural units are selected, internal documents are prepared and agreed upon, changes are made to existing internal corporate documents. 
3. Stage "Implementation": at this stage, the changes prepared in the previous two stages are being implemented. This process is characterized by the redistribution of actions and work and, as a rule, is accompanied by emotional processes, some of which will disappear over time, while others require the intervention of management.

4. Stage "Checking correctness of decision": at this stage, the correctness of the changes is realized, the belief that they were correct and effective is formed, and the employees finally realize that one of the conditions for further stay in the team is the need to fulfill their duties in accordance with redistribution of competencies of the economic security service (department), and other structural divisions for the appropriate establishment of new communications in the management system both vertically and horizontally.

5. Stage "Fixing change": at this stage the changes made in the enterprise management system due to the implementation of the economic security system cease to be something new and unusual; employees of an enterprise are accustomed to new types of work and communications in the enterprise management system vertically and horizontally, or at least do not show disagreement with them.

The adaptation of the well-known models of organizational changes and their synthesis in the implementation of the economic security system of an enterprise into the enterprise management system made it possible to show the effectiveness of these models in carrying out organizational changes, which are carried out for a specific purpose. The set of adapted models of organizational changes creates an instrumental basis for such an implementation, and their use allows us to consistently carry out organizational changes due to the implementation of the enterprise economic security system in the enterprise management system, take into account the features of organizational changes, and perform all necessary actions.

\section{Conclusion}

The capacity of the economic security system is determined by its adequacy to the enterprise management system, which is laid in the implementation of the economic security system in the enterprise management system and inevitably entails changes in the enterprise management system. Therefore, in the study of this issue we used the adapted iceberg model of S.N. Herman (to describe the adaptation of the enterprise management system to the implementation of the enterprise economic security system), L. Greiner's model of organizational change filled with concrete content (to summarize the sequence of organizational changes associated with implementation), and the adapted "change curve model" by J. Duck (to develop the fundamental sequence of measures to identify the main causes of workers' resistance and the choice of ways to counter it).

Adaptation of well-known models of organizational changes and their synthesis in the implementation of an enterprise economic security system into the enterprise management system, on the one hand, showed the effectiveness of these models in carrying out organizational changes carried out for a specific purpose - the implementation of the enterprise economic security system in the enterprise management system, and on the other hand, created the basis for the consistent and controlled implementation of strategic organizational changes due to this implementation.

\section{References}

[1]. Beer, M., \& Nohria, N. (2000). Cracking the code of change. HBR's 10 must reads on change, 78(3), 133-141.

[2]. Duck, J. D. (2001). The change monster: The human forces that fuel or foil corporate transformation and change. Currency.

[3]. Gouillart, F. J., \& Kelly, J. N. (2000). Preobrazovanie organizacii. Moscow: Delo (in Russian.).

[4]. Greiner, L. E. (1967). Patterns of organization change (pp. 67-112). Harvard Business Review.

[5]. Illiashenko, O., Rudnichenko, Y., Momot, T., \& Havlovska, N. (2020). The Enterprise Economic Security System: The State Assessment Using Management Functional Types. International Journal for Quality Research, 14(1), 183-200.

[6]. Kopytko, M. I., Levkiv, G. Y., \& Vinichuk, M. V. (2019). Dominating Effects of Globalization on the Education Model in Ukraine in the Context of Strengthening of the State Social Security. Journal of Automation and Information Sciences, 51(3), 68-76.

[7]. Kotter, J. (2007). Vperedi peremen: počemu kompanijam ne udaetsja organizacionnaja perestrojka. Moscow: Olimp-Business.(in Russian.).

[8]. Kozachenko, H. V., \& Zavora, T. M. (2019). Otsinyuvannya sotsial'no-ekonomichnoyi bezpeky Poltavs'koyi oblasti. Byznes Ynform, 4 (495), 170-181. (in Ukrainian).

[9]. Lewin, K. (1951). Field theory in social science: selected theoretical papers (Edited by Dorwin Cartwright.)

[10]. Rudnichenko, Y., Krymchak, L., Kudelskyi, V., Avanesova, N., Sokyrnyk, I., \& Havlovska, N. (2020). Minimization of Risks of the Enterprise Foreign Economic Activity through Improving the Interaction Management Quality with Potential Partners. Calitatea, 21(174), 61-67.

[11]. Herman, S. N. (1970). Cultural Iceber. TRW Systems Group.

[12]. Yılmaz, D., \& Kılıçoğlu, G. (2013). Resistance to change and ways of reducing resistance in educational organizations. European journal of research on education, 1(1), 14-21. 